УАK 616.31-053.2: 616.742.7-008.64 (048.8)

СЮ. О. Слинько

Харківський національний медичний університет

\title{
Вплив гіпофункції на стан порожнини рота (огляА літератури)
}

Резюме. Проаналізовано дані сучасної літератури щодо стану зубощелепного апарату за умов зниження функціонального навантаження на місцевому рівні й обмеження рухової активності - на загальному. Зміни порожнини рота під впливом гіпофункції характеризуються зниженням мінеральної насиченості кісткової тканини, деструктивними процесами в тканинах пародонта, порушенням мікроциркуляції, зміною складу і властивостей слини, зниженням порогів тактильної і больової чутливості слизової оболонки порожнини рота.

Ключові слова: зубощелепний апарат, гіпофункція, функціональне навантаження, рухова активність.

Ю. А. Слинько

Харьковский национальный медицинский университет

\section{Влияние гипофункции на состояние полости рта (обзор литературы)}

Резюме. Проанализированы данные современной литературы о состоянии зубочелюстного аппарата в условиях снижения функциональной нагрузки на местном уровне и ограничения двигательной нагрузки - на общем. Изменения зубочелюстной системы под воздействием гипофункции характеризуются снижением минеральной насыщенности костной ткани, деструктивными процессами в тканях пародонта, нарушениями микроциркуляции, изменением состава и свойств слюны, снижением порогов тактильной и болевой чувствительности слизистой оболочки полости рта.

Ключевые слова: зубочелюстной аппарат, гипофункция, фрункциональная нагрузка, двигательная активность.

Yu. O. Slynko

Kharkiv National Medical University

\section{Effect of hypofunction on oral health (literature review)}

Summary. Actual literature data about the state of the dentition in conditions of reduction of local functional load and limitation of general motor activity were analyzed. Changes of dental system under the influence hypofunction are characterized decrease of mineral saturation of bone tissue, destructive processes in periodontal tissues, microcirculation disorders, varying the composition and properties of saliva, reduction of tactile thresholds and pain sensitivity of the oral mucosa.

Key words: dentition, hypofunction, functional load, motor activity. 
Найбільш суттєвими негативними чинниками ризику для здоров'я сучасної людини є надмірна маса, тютюнокуріння, вживання алкоголю, незбалансоване харчування, несприятливі умови праці, моральне і психічне навантаження i, нарешті, малорухомий спосіб життя - гіпокінезія [1, 2]. На сьогодні на основі проведення експериментальних досліджень і аналізу клінічного досвіду науковці переконливо довели, що гіпокінезія чинить шкідливу, а інколи й руйнівну дію щодо практично усіх органів та систем організму людини. Встановлено, що наслідками гіпокінезії для організму людини є зменшення резервних можливостей усіх функціональних систем, зниження толерантності організму до дії подразнювальних впливів, підвищення ризику захворювань, зміни відповідних реакцій організму на лікувальний вплив тощо [3, 4]. На тлі недостатньої рухової активності відбуваються суттєві зміни в функціонуванні опорно-рухової, серцево-судинної, травної, нервової, ендокринної, імунної, сечостатевої, репродуктивної систем.

Питання стану зубощелепного апарату за умов зниження функціонального навантаження на місцевому рівні й обмеження рухової активності - на загальному, почало привертати увагу дослідників ще у 70-80 роках минулого століття. Так, в експерименті на собаках і за допомогою рентгенологічних досліАжень було встановлено вплив недовантаження на зубні ряди, що виявляється вже з 10-денного терміну спостережень і характеризується дрібнопетлистим малюнком міжзубної перегородки у ділянці роз'єднаних зубів із прогресуючою резорбцією кісткової тканини альвеол. Атрофія альвеолярного відростка також супроводжувалася значною тканинною перебудовою з утворенням пародонтальних кишень, розширенням періодонтальної щілини. В результаті зниження фрнкціонального навантаження на пародонт відбувалося зменшення кількості кальцію при відносно постійному рівні фосфору. В наслідок цього знижувалося співвідношення Са/P у кістковій тканині, що свідчить про якісні зміни в кристалах гідроксиапатиту [5]. Тобто основні механізми розвитку змін у кістці при гіпофункції жувального апарату можуть бути пояснені місцевим фрактором зняття навантаження і зниженням регенераторного потенціалу кістки. Все це викликає порушення живлення клітин кісткової тканини, посилення функції остеокластів і ослаблення остеобластів, за результатами чого відбувається переважання процесів деструкції над процесами синтезу.

Судинно-біомеханічна концепція захворювань тканин пародонта [6-9] базується на визнанні необхідності функціонального навантаження всіх елементів зубощелепної системи. Стан місцевої гіпофункції гальмує обмінні процеси в альвеолярній кістці та інших структурних компонентах пародонта. На думку авторів, лише належне оклюзійне навантаження здатне забезпечити нормальний рівень кровообігу та звапнення кісткової матриці мінеральними компонентами, покращити метаболізм тканин пародонта, i, як наслідок, збільшити адаптаційні можливості опорноутримувальних тканин зубів.

Аослідження впливу екстремальних фракторів, у тому числі й гіпокінезії, на функціональні, клінічні, мікробіологічні, імунологічні та цитологічні показники стану пародонта стає все більш актуальним. Але не тільки через зростання фактора обмеження звичайної рухової активності людини, а ще й через розвиток так званих космічних програм.

В експериментальному недовантаженні пародонта, яке зумовлене гіпокінезією організму, в слизовій оболонці ясен виявлено застійні явища, ïï розпушення, набряк і гіперемію, що відповідає картині хронічного катарального гінгівіту. В частини тварин патологічні зміни прогресували навіть до утворення пародонтальних кишень, що говорить про розвиток пародонтиту [10].

3 результатів дослідження у людини в умовах 30-добової гіпокінезії виявлено підвищення чутливості зубів до вертикального і горизонтального навантажень вже до 10-го дня спостереження. Аані дослідження тактильної і больової чутливості слизової оболонки ясен у здорових чоловіків, які знаходяться в умовах суворого постільного режиму, свідчать про зниження порогів тактильної і больової рецепції ясен. Встановлений факт спостерігається починаючи вже з 3-денного терміну і залишається нижче норми протягом 30-ти діб експерименту. Також виявлено, що зниження функціонального навантаження на пародонт викликало підвищення ступеня проникності й стійкості капілярів, що порушувало гемодинаміку тканин. У практично здорових осіб 
30-добова гіпокінезія викликає суттєві зміни чутливості деяких зон слизової оболонки порожнини рота, зниження їі порогів. Це має важливе значення через те, що саме смакова чутливість зумовлює адекватність оцінки спожитої їжі, визначає процес слиновиділення, має прямий зв' язок з функціональним станом органів шлунково-кишкового тракту [5, 11]. Крім того, з'ясовано, що при гіпокінезії в перші 60 діб відбувається посилення кровотоку, а на 120 добу - його компенсаторне зниження [5].

Порушення судинного тонусу і кровотоку супроводжується зміною мікробіоценозу порожнини рота, що виражається у збільшенні кількості бактерій, здатних підтримувати запальний процес в тканинах порожнини рота, а також появою пародонтопатогенних мікроорганізмів - Prevotella melaninogenica, Actinomyces israelii, Actinomyces naeslundii i Fusobacterium nucleatum - на тлі зникнення груп бактерій (наприклад Veillonella spp.), що є складовими нормального мікробіоценозу порожнини рота. В результаті збілышення пародонтопатогенних мікроорганізмів відбувається підвищення вмісту імуноглобулінів у ротовій рідині, що може бути наслідком сенсибілізації патогенною мікрофлорою імунокомпетентних тканин порожнини рота [5, 12-14].

Питання впливу гіпокінезї набувають останнім часом особливої актуальності через те, що стан обмеженої рухової активності притаманний сучасним жінкам під час вагітності. Аослідники встановили, що такий спосіб життя майбутньої матері впливає на розвиток плоду, поєднується зі збільшенням частоти акушерської і перинатальної патології, погіршує адаптацію новонародженого до позаутробного існування [15-17]. Але відомостей про вплив гіпокінезії матері на стан органів та тканин порожнини рота, зокрема пародонталь-

\section{Список літератури}

1. Грузєва Т. С. Фактор ризику в формуванні здоров'я населення / Т. С. Грузєва // Вісник соціальної гігієни та організації охорони здоров'я. - 2003. № 2. - C. $9-16$.

2. Нагорна А. М. Соціально-економічні детермінанти здоров'я населення України / А. М. Нагорна // Журн. АМН України. - 2003. - Т. 9, № 2. - С. $325-345$.

3. Качелаева Ю. В. Гиподинамия и здоровье человека / Ю. В. Качелаева, Р. Р. Тахаутдинов // В мире научных открытий. - 2010. - № 4. - С. $26-27$. ного комплексу, в їх нащадків у доступній науковій літературі не знайдено.

Таким чином, узагальнюючи наявні відомості про вплив обмеження рухової активності на організм людини, можна зробити висновок, що гіпокінезія викликає істотні зміни обмінних процесів та дисфрункцію практично усіх органів та систем, у тому числі й зубощелепної. Так, зміни останньої характеризуються зниженням мінеральної насиченості кісткової тканини, деструктивними процесами в тканинах пародонта, порушенням мікроциркуляції, зміною складу і властивостей слини, зменшенням порогів тактильної і больової чутливості слизової оболонки порожнини рота та ін. Але проведений аналіз даних літератури свідчить, що до цього часу немає повної ясності у розумінні природи морфофункціональних, біохімічних, імунологічних, мікробіологічних змін у тканинах пародонта, викликаних дією гіпокінезії. Також зовсім не визначені механізми впливу стану недостатньої рухової активності майбутньої матері на тканини пародонта їхніх дітей. У цьому зв'язку поглиблене вивчення механізмів гіпокінетичних розладів у тканинах пародонта є своєчасним і необхідним. Безумовно, через вищезазначене потрібен пошук нових підходів та переосмислення існуючих профілактичних програм для зниження рівня хвороб пародонта з урахуванням особливостей рухової активності сучасної людини. Саме розробка заходів профілактики і корекції наслідків гіпокінезії набувають великого соціального значення. I, нарешті, знання особливостей та закономірностей фрормування здоров'я населення, впливу на нього різних факторів ризику, є підГрунтям Аля розробки комплексу заходів первинної профілактики, спрямованих на попередження їх негативного впливу, поліпшення якості життя населення.

4. Гиподинамия как стрессовый фактор / С. А. Лобанов, Т. Ф. Емелева, А. В. Аанилов [и Ар.] // Медицинский вестник Башкортостана. - 2006. - Т. 1, № 1. C. $72-74$.

5. Брагин А. В. Клинико-физиологический статус лиц с различной устойчивостью к кариесу зубов и заболеваниям пародонта (механизмы резистентности, основы системной профилактики и комплексного лечения) : автореф. дисс. на соискание науч. степени А. мед. наук : спец. 14.00.21, 03.00.13 / А. В. Брагин. Тюмень, 2008. - 37 с.

ISSN 231 1-9624. Кпінічна стоматопогія. 2014. № 2 
6. логинова Н. К. Функционально-диагностическая оценка механического фактора, как риска развития заболеваний пародонта и способы их профилактики / Н. К. Аогинова, И. Е. Гусева : материалы XIV и XV всероссийских научно-практических конференций и Труды Х съезда Стоматологической Ассоциации России. - 2005. - С. 282-285.

7. Логацкая Е. В. Исследование влияния использования жевательной резинки на кровоснабжение жевательных мышц : автореф. дисс. на соискание науч. степени канд. мед. наук : спец. 14.00.21 / Е. В. Логацкая. - Москва, 2005. - 24 с.

8. Аогинова Н. К. Метод гнатотренинга / Н. К. Аогинова // Новое в стоматологии. - 2003. - № 1. C. $21-24$.

9. Аогинова Н. К. Влияние жевательных нагрузок на напряжение кислорода в тканях пародонта / Н. К. Аогинова, О. В. Крылова // Стоматология. 2001. - № 1. - C. $23-25$.

10. Струев И. В. Изменения в органах и тканях зубочелюстной системы после шокогенной политравмы и в восстановительном периоде. Пути профилактики : автореф. дисс. на соискание науч. степени канд. мед. наук / И. В. Струев. - Омск, 1998. - 18 с.

11. Будылина С. М. Физиология челюстно-лицевой области / С. М. Бурдылина, В. П. Аегтярев. - М. : Медицина, 2000. - 352 с.

12. Сакварелидзе И. В. Состояние местного иммунитета и микрофлоры полости рта у космонавтов, со- вершивших космический полет на МКС / И. В. Сакварелидзе // Российский стоматологический журнал. - № 4. -2005 . - C. 14-17.

13. Long-term physical inactivity and oral health in Finnish adults with intellectual disability / S. Karjalainen, V. Vanhamaki, D. Kanto [et al.] // Acta Odontol. Scand. - 2002. - Vol. 60(1). - P. 50-55.

14. Interaction peculiarities between microbial cenosis and local immunity of periodontium of humans under extreme conditions / A. I. Volozhin, V. N. Tsarev, N. S. Malneva [et al.] // Acta Astronaut. - 2001. Vol. 49(1). - P. 53-57.

15. Кондратьева И. Особенности развития длинных трубчатых костей плодов белых крыс при воздействии вибрации, шума и гипокинезии / И. Кондратьева / / Симпозіум з проблем космічної біомедицини : матер. наук.-практ. конф. (Київ, 10-11 квітня 2002). - Київ : НМУ, 2002. - С. 43-44.

16. Никишина С. Влияние гипергравитации и гипокинезии на пренатальное развитие костей плечового и тазового пояса белых крыс / С. Никишина : симпозіум з проблем космічної біомедицини : матер. наук.практ. конф. (Київ, 10 - 11 квітня 2002). - Київ : НМУ, 2002. - C. $42-43$.

17. Чернышова О. Н. Гипокинезия во время беременности и степень ее влияния на формирование механизмов иммуносупрессии / О. Н. Чернышова, ^. Ф. Зюбанова, Э.Н.Будянская // Иммунология. 1998. - № 4. - C. 49 - 52. 